\title{
Meeting the Habitat Needs of Non-game Forest Wildlife
}

\author{
by
}

\author{
Daniel A. Welsh ${ }^{1}$
}

\section{Introduction}

At the last of four biologists to speak about wildlife habitat I feel like a fox returning to the henhouse four nights running perhaps it is once too often - I hope no one is gunning for me.

We have heard about big mammals that you can eat and smaller ones with valuable fur; it falls to me to talk about all the 'other stuff': like shrews, groundhogs, warblers, and eagles to name a few. You will be relieved to know that I do not plan to detail the habitat needs of the 455 species of reptiles and amphibians, 395 species of mammals and 650 species of birds in North America that are not hunted or trapped for fur.

What I shall do is try to define 'non-game' (a term I truly wish we could do away with), consider the question of who's responsible for non-game wildlife, look at a couple of examples of non-game wildlife-forestry interactions and then briefly examine the problems of trying to develop management plans for 'non-game wildlife'.

\section{What is Non-game?}

To be clear about what I'm talking about I wish to start by trying to anwer the question 'What is non game'? Most of us are familiar with some of the terms that have been used in the past to describe non-game: "dickie birds, vermin" and so on. Fortunately those derogatory terms and the attitudes that they imply have now largely disappeared and have been replaced by sound ecological knowledge and responsible environmental feelings and concerns. Most of you recognize that there are a lot of challenges in dealing with non-game wildlife and I suspect are looking for sound approaches to deal with these challenges.

I should compliment the organizers for allowing me to set my own rules; I have not been told what non-game wildife included. I am not really sure what most of you think but I would imagine that large birds especially raptors like eagles and hawks would certainly be non-game; probably small birds for most of you, and maybe small mammals. I suspect that most of you would not wish to include turtles and toads - some of you might want to include turtles and toads - some of you might want to include butterflies but many wouldn't. Most of you would say "No, we don't want to include plants", but I think it is also true that if you knew that a plant were of particular interest because of its range or because it were threatened in some other way I am certain that none of you would want to see it

Canadian Wildlife Service, Ottawa, Ont destroyed. In northern Ontario, I know of several out-of-range white pine and red pine stands that inexplicably have not been cut.

Most people think of vertebrates when they think of wild life. I would argue that you can't exclude the other animals from your thinking when you plan forests - whether you call them wildlife is really a matter of taste. In the case of plants I would argue that they must also be considered in forest management planning although I personally don't usually think of them as "wildlife". Perhaps viewing 'non-game' wildlife as all the other stuff is reasonably accurate.

\section{Responsibility for Non-game Wildlife}

The formal legal responsibility for non-game wildlife varies in the various jurisdictions in Canada but ultimately the responsibilities of the resource manager must extend to all the resources affected by his activities not just the direct and immediate resource that he is specifically looking after. In Ontario The Environmental Assessment Act effectively requires complete knowledge of the impact of an activity on the total environment. Long-term integrity of the forest ecosystem must be based on the shared responsibilities of everyone managing the forest ecosystem. I think we are all aware of the combined destructive effect of the 'poor majority and affluent minority' of mankind on the biosphere. Deterioration of the world's biosphere will continue until we have a new environmental ethic of sustainable development. One prerequisite of sustainable development is true conservation of living resources. The definition of conservation that I like best is from the World Conservation Strategy (IUCN, 1980). It defines conservation as "the management of human use of the biosphere so that it may yield the greatest sustainable benefit to present generations while maintaining its potential to meet the needs and aspirations of future generations".

This concept is based on two basic properties that distinguish living resources; they are renewable if conserved and are destructible if not. Both development and conservation are for people. Development is directed to achieving human goals through use of the biosphere while conservation aims to achieve human goals by ensuring that the biosphere can continue. Conservation concerns are rational considering the basic renewability-destructibility character of living resources. I think this basic philosophy is best expressed by the belief that 'we have not inherited the earth from our parents but rather we have borrowed it from our children'. 
The basic objectives of the World Conservation Strategy are: 1) to maintain essential ecological processes and life support systems; 2) to preserve genetic diversity, and 3) to ensure sustainable utilization of species and ecosystems. The Government of Canada has officially endorsed the goals of the World Conservation Strategy and these objectives can clearly be directly applied to forest management.

The National Forest Sector Strategy for Canada sponsored by the Canadian Council of Forest Ministers and agreed to in St. John, New Brunswick in July of 1987 provides further support for the broad responsibilities concept. Specifically the strategy says "It is recommended that all elements of the forest sector assist in the development of provincial conservation strategies, endorse those strategies where appropriate and ensure that forest management goals and practices meet requirements for sustainable development. It is recommended that forest management planning for industrial raw material and other benefits of the forest focus on maintaining the long-term dynamics of healthy, stable and well-balanced forest ecosystems. It is recommended that foresters and wildlife managers cooperate in the review and development of forests, fisheries, wildlife and integrated management. More specifically the review might consider the establishment of short- and long-term objectives for forest management, developing integrated planning processes, converting wildlife information into usable forest technology, implementing harvesting and silvicultural practices and assessing the achievement of objectives in terms of wildlife response and the examination of costs and benefits to support the enhancement of wildlife habitat. It is recommended that planning processes be fostered that encourage the development of specific and measureable objectives for the management of defined areas of land including timber and non-timber values such as wildlife, fisheries and recreation."

\section{Forest Bird Communities}

Although I did promise not to outline the habitat requirements of all North American non-game I am going to look at a few examples that may provide insight into the problem.

For two reasons I would like to start with a discussion of forest bird communities because birds are one of the more interesting and exciting groups of animals that live in our forests and they typify the problems that we have to deal with in non-game wildlife management. I am going to draw principally on work done in the boreal forest in Ontario and thereby deal with a land base that everyone here knows (Welsh 1983, 1987; Welsh and Fillman 1980). In the mixedwood forest of Ontario we have more than 80 species of song-birds. Figure 1 shows the general structure of forest stands through a successional continuum from newly cut stands to old over mature stands. We can see that the relative contribution of different tree components (small trees, large trees and saplings) changes dramatically and that the shrub component changes as well throughout the successional continuum. Surely this is not news to any of us - we all know that the forest is not static but has a very dynamic structure. If we now examine the bird species associated with those different stages we can see in Figure 2 that the species that occur in the early successional stages drop out and are replaced by mid-successional species and finally by other species that are much more common in the mature forest. Again I suspect that this is not terribly surprising to many of us but it is important to keep in mind - it's certainly difficult to manage for all of them in one place at one point in time.

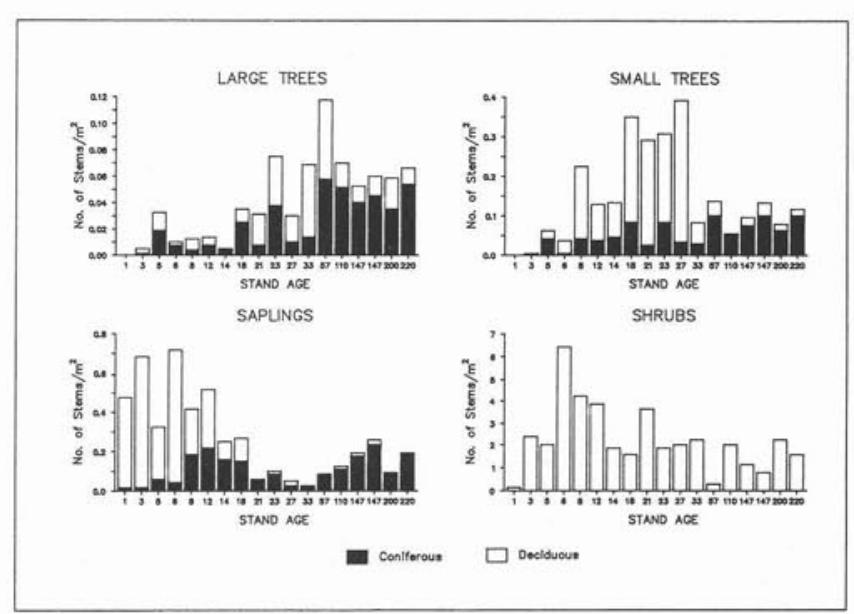

Figure 1. Density of stems of arborescent vegetation in relation to stand age in mixedwood forest.

The other aspect of forest bird communities that I want to draw to your attention is a comparison of upland and lowland forests - again we shall look at a stylized diagram. Figure 3 shows that the pattern of regrowth in a typically harvested lowland stand is quite different from that in a typically harvested upland stand. In a clear-cut lowland there is relatively rapid shrub proliferation, usually speckled alder and some willows, with conifers regenerating as the stand gradually matures. In upland mixedwood there are usually quite a few trees left behind and the forest regrows between already standing trees resulting in a very different forest structure from the time of cutting onward. If we now look at Figure 4 where I have grouped bird species associated with

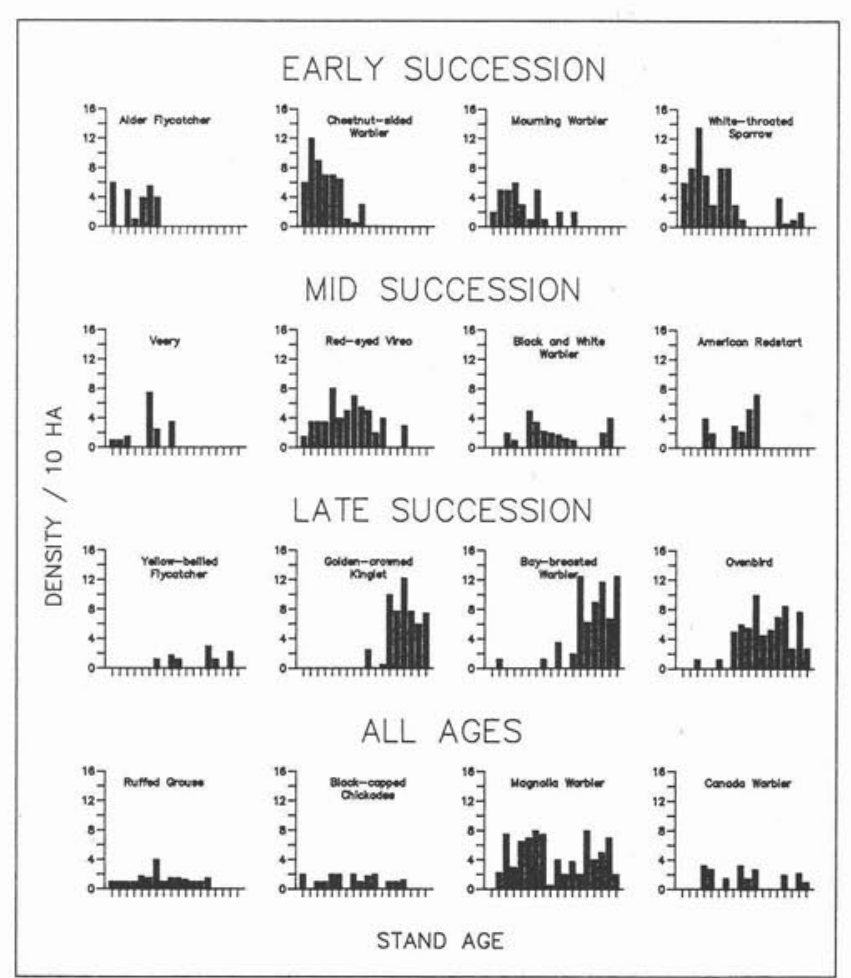

Figure 2. Examples of individual bird species distribution patterns relative to forest stand age. Ages as in Fig. 1. (Based on Welsh 1987.) 


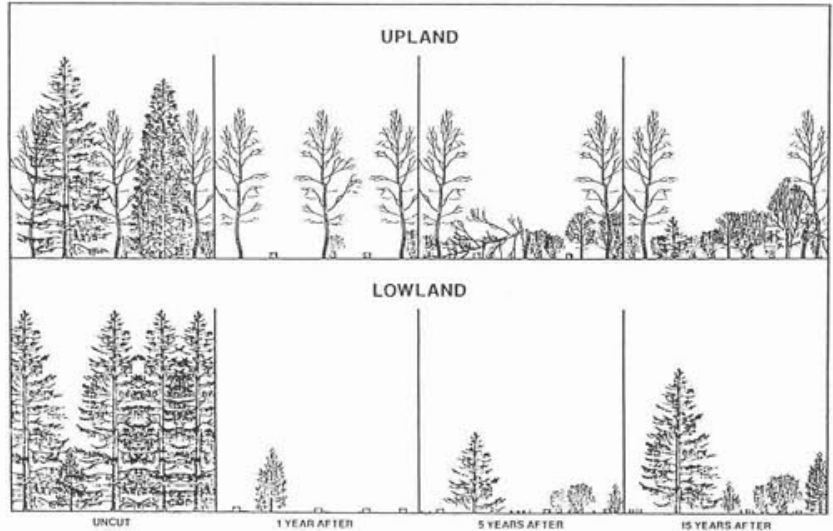

Figure 3. Schematic section of upland and lowland forest before cutting and at 1,5 , and 15 years after selective conifer removal in uplands and conifer clearcutting in lowlands. (From Welsh 1983).

stages of regeneration of lowland, mesic and upland sites we can see that in fact the upland bird communities are a distinct and separate unit from the lowland bird communities both of which are separate from the mid-slope mesic communities.

For the past few years I have been studying, with my colleague Jacques Régniere of the Canadian Forestry Service, the effect and relationship of bird predation on spruce budworm population dynamics. We have not finished that work by any means but over the past two years in a declining budworm population there has been significant budworm mortality that we can best explain as avian predation. So the

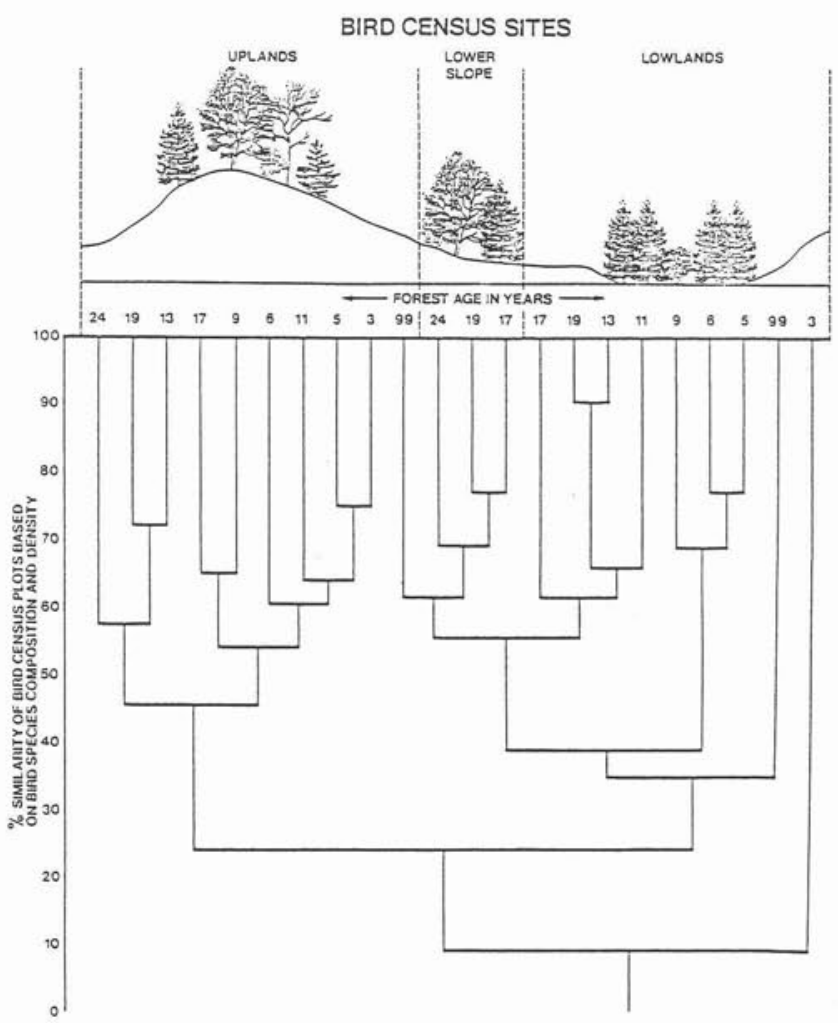

Figure 4. Cluster diagram of bird communities based on similarity of bird species composition and density. The relative topographic position and age of the community sites are indicated above the clusters. (From Welsh 1983). birds that we are discussing may in fact have an important regulatory role in the control of insect pests.

\section{Small Mammals, Truffles and Trees}

One must objectively study and understand the role of each species as a functioning component of the dynamic ecosystem before designating a species as detrimental to the objectives of forest management. There has been considerable interest in the potential negative impact that seed eating small mammals might have on forest regeneration. As we shall see just the opposite might be true.

In Ontario, (Martell 1979, 1981) found that seed predation on conifers was unlikely to significantly affect the stocking rates in natural or man-made disturbances since small mammals do not include appreciable quantities of conifer seeds in their diets. He did show (Martell 1983a, b) that dramatic changes occur in some small mammal communities following cutting and as you might expect the pattern of change varied considerably with stand type. In upland black spruce a totally new small mammal community developed within one to two years after cutting and remained stable for at least 13 years. In mixedwoods the changes were more strongly related to the topographic position than to the age of the cutover. In general, he found the Clethrionymes gapperii, the southern red-backed vole, tended to decrease following cutting and that Peromyscus maniculatus, the deer mouse tends to increase. The point I wish to make is that cutting results in major changes that follow different patterns in different stand types.

Most higher plants have a strong obligatory symbiotic relationship with fungi (Marks and Kozlowski 1973, Sanders et al. 1975). Increasingly the importance of that relationship to the nutrient regime of many trees is being realized. At the risk of becoming too specialized I would like to talk about ectomycorrhizal fungi: those fungi that specialize in living on only the succulent root tips of woody plants. The hosts of ectomycorrhizal fungi include all of the Pinaceae, the Betulaceae, the Salicaceae and most other temperate trees. There are two types of fruiting bodies in the ectomycorrhizal fungi. There are epigeus or above ground fruiting bodies, the standard mushrooms, and hypogeous or below ground fungi, the truffles. Many of these are host specific.

One thing that distinguishes the truffles is that as the spores mature they undergo chemical changes so that they gradually develop a characteristic odour that serves as a signal to animals that they are ready to be eaten. Unlike the mushrooms which pass their spores on principally by releasing them into the air most of the underground fungi reproduce by transmitting their spores through the gut of a small mammal. This is not a random system for them - the animals that feed on them are forest and forest-edge species and the spores are regularly carried to sites where colonization is possible (Fogal and Trappe, 1978, Maser et al. 1978). We now know that many forest dwelling squirrels, mice and voles preferentially dig out and feed on truffles. Increasingly as well we are finding that there is a strong interrelationship between the germination and healthy growth of most trees and the presence of ectomycorrhizal fungi. The basic conclusion that I am suggesting is that the invasion of clear-cut and burned, non-forested land by trees that require ectomycorrhizal fungi can be enormously assisted by small mammals. Indeed it may not be possible in the long run in the absence of small mammals that transmit symbiotic fungi. 
Although deer mice and other species are able to colonize naturally regenerating clear-cut we do know that it is possible to make clear-cuts totally inhospitable for small mammals. I suspect that by so-doing we doom the trees there to much slower regeneration and growth and in some cases will make it impossible for them to thrive.

\section{Managing Non-Game Wildlife - The Species Specific Approach}

In most North American jurisdictions where timber is the primary product of the forest the usual approach to land management is to develop a timber plan to which other values like wild life and fisheries are added as 'constraints' or 'areas of concern'. We have seen in some cases, like the "Ontario Moose Habitat Management Guidelines", that the scope can be rather far-reaching.

The National Forest Management Act of 1976 (NFMA) in the United States requires the monitoring of all renewable resources in the National Forests. Under subsequent specific policies and guidelines each National Forest must select "management indicator species" that represent fish, wildlife and plant resources in four categories: 1) species on state or federal lists of threatened and endangered species; 2) harvested species or species known to have high value for non-consumptive recreational use; (3) species restricted to habitats likely to be significantly affected by management activities in the Forest, and (4) species considered to be good indicators of trends (in quality and quantity) in habitats important to other species (Verner 1983). Regulations require that forests be monitored for population trends in all management indicator species.

From an ecological point of view a major concern with the indicator species concept is that other members of the species guild supposedly represented may in fact respond very differently to an identical environmental perturbation; thus simple species monitoring can easily lead to major errors. The guild concept was originally based on a recognition of similar not identical use of resources; management needs may have resulted in an overemphasis of the similarities.

Management experience is increasingly showing that, in addition to the ecological problems, the practical problems of trying to develop and implement monitoring and the high associated costs are frequently rendering such efforts totally impractical. Indirect monitoring of wildlife through habitat monitoring is being recognized more and more as a more practical long-term solution. This emphasis can be seen in the extensive development of Wildlife Habitat Relationship models (WHR). Direct monitoring efforts which are an essential first step in indirect modelling are being expanded to include combined guild counts of all guild species rather than single featured species. Such guild counts effectively give a measure of general quality and quantity of habitats with greater precision and reduced costs and effort. Eventually limited guild based multi-species counts coupled with detailed monitoring of habitat will be the major efforts in meeting NFMA requirements.

I would like to draw your attention to another major effort; the Habitat Suitability Index Models that have been established for a large variety of species by the US Fish and Wildlife Service. There are now more than a hundred of these: for example, slider turtle, bald eagle, lark bunting and bull frog.
Each one provides a detailed model of habitat needs for the species. If we consider the usual approach of adding wildlife values to timber management plans as 'areas of concern' then you can imagine the large number of layers that could be added. This logical extension of the specific species approach clearly leads to a logistical nightmare.

In the last Canadian Forestry Wildlife Management symposium in Vancouver in 1984, Jack Ward Thomas described several games that are frequently played by timber managers and wildlife managers (Thomas, 1985). I think there are two of particular potential in dealing with non-game species. A favourite of wildlife biologists is 'We Don't Know Enough'. In this game "the biologist refuses to be contaminated by participating in anything as grubby as forest management while pretending to take part. Pretence takes the form of responding to all queries for knowledge by emphasizing how little is really known about wildlife-forestry relationships while ignoring the considerable amount that is known". Thomas tells us that some students of games claim that this game is nothing more than a variation of the old generalized standby - "Stop the world I want to get off". It is staggering to think of the enormous scope for playing "We Don't Know Enough" with the hundreds of non-game species available. Faced with a game-playing wildlife biologist, the game-playing timber manager can appropriately respond with a game of his own; I think the most likely choice would be "Prove It". In this game the constrainee essentially says, "I don't believe that the constrainer is correct, and I will not be constrained until somebody proves it. A good 'Prove-it' player tries to retain the right to make all final decisions as to when something is indeed proven. Some scholars believe that this game is related to the essentially military game of Catch 22 . As in all games the opponents are adversaries and there are winners and losers. I believe we must question whether we want the fate of future forests and wild life to be decided by who wins a game.

There are few relationships as complex as that between insect pollinators and plants. Recently I have seen several papers examining butterfly distribution in Finland in relation to forest succession. A dilemma of species oriented management is that it may not provide the flexibility needed to deal with new or unforseen consideration such as butterflies. It is likely that tomorrow we shall be concerned about species that are not the focus of our concern today. The resource manager must develop plans for the present but also for the future. We need flexibility as well as facts. Todays truths and priorities become old hat as species of concern change.

\section{Forest Ecosystem Management}

Faced with the large number of non-game species of concern, the lack of knowledge about the role of many in the ecosystem, and the uncertainty of future priorities I don't see any easy roads. I do believe that a major change in approach is required.

To develop effective forest management plans all of the various objectives have to be openly stated and generally agreed upon before planning starts. Conflicts must be openly discussed and resolved.

It is impossible to grow mature forests and have early successional species living there and vice versa. We have to decide on an appropriate land use pattern and then set about establishing it. At the same time we have to ensure that we are 
in the long run preserving the integrity of the forest ecosystems. Once goals are established we need a partnership of timber and wildlife managers to develop forest management plans from the start. It is clear that the intent of the World Conservation Strategy and the National Forest Sector Strategy for Canada is to manage on an ecosystem basis for all the values of the forest - trees, other plants, and wildlife. This can only be done with dynamic plans that take into account the successional character of forests.

Forest planning for multiple products has to be done on a scale that ensures the long term existence of all respresentative ecosystems. We could easily block out habitat for groups of wildlife species by forest type, and age and then build those blocks into the plan from the beginning to ensure their continued existence. I believe that we now have the technical information available to guess what sort of ecosystems we need to leave to preserve sufficient habitat diversity to protect wildlife and maintain a sound forest ecosystem.

At present there are a number of geographic information systems (GIS) available for micro and mainframe computers that make dealing with this type of spatial planning practical. It is possible to put in detailed maps of a management unit by soil type, topographic structure, rivers, lakes, details of forest type and age, and then to develop a series of models for different road plans and cutting plans that meet stated prerequisites and provide the spatial plan we want. I am not saying that it is easy because certainly there is a lot of work involved, but from a computational point of view the problems are now trivial and there is not much stopping us from getting on with the job. Once you have a broad ecosystem based plan experts can use tools like the Habitat Suitability Index Models to verify that as far as possible the needs of the various species are being taken into account.

I believe that the only way we are going to have productive forests with the values we all want protected is if managers jointly develop ecosystem based management systems. Managing timber without paying attention to the total forest ecosystem means we are living on borrowed time.

\section{References \\ Canadian Council of Forest Ministers. 1987. A National Forest Sector Strategy for Canada. For. Chron. 63: 310-333. \\ Fogal, R. and J.M. Trappe. 1978. Fungus consumption (mycophagy) by small mammals. Northwest Science 52: 1-31. \\ International Union for Conservation of Nature and Natural Resources (IUCN). 1980. World Conservation Strategy Living}

Resource Conservation for Sustainable Development. IUCN. Gland.

Marks, G.C. and T.T. Kozlowski. 1973. Ectomycorrhizae: their ecology and physiology. Academic Press, New York.

Martell, A.M. 1979. Selection of conifer seeds by deer mice and redbacked voles. Can. J. For. Res. 9: 201-204.

1981. Food habits of southern red-backed voles (Clethrionomys gapperi) in northern Ontario. Can. Field-Nat. 95: 325-328.

1983a. Demography of southern red-backed voles (Clethrionomys gapperi) and deer mice (Peromyscus maniculatus) after logging in north-central Ontario. Can. J. Zool. 61: 958-969.

1983b. Changes in small mammal communities after logging in north-central Ontario. Can. J. Zool. 61: 970-980.

Maser, C., J.M. Trappe and R.A. Naussbaum. 1978. Fungal-small mammal interrelationships with emphasis on Oregon coniferous forests. Ecol. 59: 799-809.

Sanders, F.B., B. Mosse and P.B. Tinker. 1975. Endomycorrhizas. Academic Press, London, England.

Thomas, J.W. 1985. Toward the managed forest - going places that we've never been. Wild. Soc. Bull. 13: 197-201.

Welsh, D.A. 1983. Use of the mapping method to study the effects of forest cutting on boreal bird populations. In: Purroy F.J. (ed), Bird Census and Mediterranean Landscape. Leon, 8-12.

1987. The influence of forest harvesting on mixed coniferous-deciduous boreal bird communities in Ontario, Canada. Acta Oecol. 8: 247-252.

Welsh, D.A. and D.R. Fillman. 1980. The impact of forest cutting on boreal bird populations. Am. Birds. 34: 84-94.

\section{Additional Readings}

Anom. 1985. Canadian Forestry and Wildlife Management Symposium. For. Chron. 61: 123-202.

Gutierrez, R.J. and A.B. Carey. Tech. eds. 1985. Ecology and management of the spotted owl in the Pacific Northwest. USDA, Gen. Tech. Rep. PNW-185, Portland.

Lynch, J.F. and D.F. Whigham. 1984. Effects of forest fragmentation on breeding bird communities in Maryland, USA. Biol. Conser. 28: $287-324$.

Simberloff, D. 1987. The spotted owl fracas: mixing academic, applied, and political ecology. Ecol: 766-772.

Thompson, I.D. 1988. The myth of integrated wildlife/forestry management. Queen's Quarterly. In press.

Verner, J., M. Morrison, and D.J. Ralph. 1986. Wildlife $2000-$ Modelling Habitat Relationships of Terrestrial Vertebrates, Univ. of Wisconsin Press, $470 \mathrm{pp}$.

Whitcomb, R.F., C.S. Robbins, J.F. Lynch, B.L. Whitcomb, M.K. Klimkiewicz and D. Bystarak. 1981. Effects of forest fragmentation on Avifauna of the eastern deciduous forest. In: Burgess, R.L. and D.M. Sharpe (eds.), Forest Island Dynamics in Man-dominated Landscapes, Spring-Verlag, New York. 125205.

Wilcove, D.S. and R.F. Whitcomb. 1983. Gone with the trees. Nat. History. 9: 83-91. 